\title{
Objects of Hate? Architectural Symbols of the Rich in Turkey in the 1960s
}

\begin{abstract}
It is unfortunately true that there is social injustice in our country. A fortunate class exploits housing potentials and acquires houses which would be considered luxurious even in rich countries; resources are seized to the disadvantage of other classes. ${ }^{1}$
\end{abstract}

This quotation is from the Chamber of Architects' declaration published a few months after the military intervention in 1960. Although it did not attack the military regime, the text openly criticized the failure of the military to implement effective regulations regarding housing and urbanization. As the quotation reflects, the Chamber's declaration represents the urgency of the housing question as well as the Chamber's position with respect to it. Yet, it was none other than architects, who were designing the houses, which "would be considered luxurious even in rich countries." The tension between the client-dependent nature of the architectural profession and the Chamber's opposition to urbanization led by the private sector would prevail throughout the following decades. Nonetheless, this tension allows us to consider the multifaceted character of architecture which is simultaneously a service to be bought and a social product to be consumed.

I would like to use this intrinsic conflict between the private ownership of buildings and their social use as a starting point for my discussion on the cultural politics of the housing question in Turkey in the 1960s. I will argue that a key mode of consuming architecture is through vision: the visual experience of the built environment establishes the foundation for the social meanings of architecture. Therefore, my aim here is to scrutinize the political role of architectural representations of home in popular culture in the 1960s. As scrutinized by the chapters in this collection, the period witnessed radical changes in almost all facets of social life. Urban life transformed under pressure of multiple factors and led to the emergence of new social practices. Social change encompassed all sorts of domains and cultural production was no exception. New trends and lifestyles displayed social distinction, which triggered conflicting visions regarding the city and its built environment. Within this framework, I will show how cultural representations were not merely reflections of wealth and poverty, but rather components in the making of the imaginations of the rich and the poor. My main object of inquiry in this endeavor will be the cinematic production of the period. The 1960s represented the

1 Chamber of Architects, Bildiri 1960: Yurdumuzda İmar Çabalan (Ankara: Chamber of Architects, 1960), 25. 
heyday of Turkish cinema and the widespread influence of cinema in this period turned it into the most powerful instrument in producing cultural representations of home. ${ }^{2}$ In the absence of television, cinema was the main entertainment source. The films (which were heavily influenced by Hollywood movies) played an important role in shaping popular culture and taste. This included images of home and domesticity as well. Therefore, there was a strong relationship between cinema and the popular architectural culture of the period. Below I will discuss the cultural politics of these cinematic representations with reference to the social context of architectural production in the 1960s.

\section{Longing for Home}

The housing question was one of the most pressing problems in Turkey due to continuous rural-to-urban migration since the 1950s (Karpat 1976; Keleş and Danielsen 1985). Within a decade (between 1950 and 1960) 1.5 million immigrants arrived into urban areas (600,000 into the four largest cities) and the urban population rose from 19 to 26 percent of the nation's total (Karpat 1976, 59-63). While the newcomers found jobs first in services and then in industry, they produced shantytowns (gecekondu) as their living environment in the outskirts of the big cities. The question of gecekondu (which in Turkish literally means "landed in one night") from then on was going to trouble politicians and planners as well as the literature on the experience of Turkish urbanization. The problem was mostly defined as shortage of shelter for the squatters. It was believed that providing adequate housing for the newcomers would be the first step towards their integration into urban life, and hence, their modernization.

The first half of the 1960s witnessed a series of events organized by various institutions to produce solutions to the housing problem (Batuman 2006, 59-81). ${ }^{3}$ The technocrats of the State Planning Organization (Devlet Planlama Teşkilatı,

2 The reduction of municipal taxes on Turkish films in 1948 opened a new era for Turkish cinema. After this date, the number of films produced per year gradually increased. The number of films produced annually rose from 22 in 1950 to 82 in 1960; and between 1965 and 1975, the average yearly production was above 200. See Dilek Kaya Mutlu, "Between Tradition and Modernity: Yeşilçam Melodrama, its Stars, and their Audiences,” Middle Eastern Studies 46: 3 (2010): 417.

3 These institutions include the Ministry of Reconstruction and Resettlement (Second Reconstruction Congress, 1962; People’s Housing Standards Seminar, 1965), workers' unions (First and Second Turkish Workers' Construction Cooperatives Conferences organized by Türkİş in 1961 and 1964; the Housing Seminar by TEKSIF in 1964), and universities (First and Second Housing Panels organized by ITU Building Research Institute in 1963 and 1965). 
DPT) argued that the demand for housing production could only be met by discouraging luxurious construction and implementing mass housing methods. They viewed the problem of "luxurious housing" as a serious issue of social injustice. For instance, in the "Housing Seminar" organized by TEKSIF, the Textile Workers' Union of Turkey in 1964, Tulgar Can of the Social Planning Department of the DPT stated that luxurious houses built for extravagant expenses were "as harmful to the country's social body as the gecekondu [squatter houses]" (Can 1964). ${ }^{4}$

Moreover, the technocrats' distaste towards luxurious housing was also directed towards home ownership in general. During the Seminar, when Charles Hart, the Chair of the Department of Social Anthropology in Istanbul University, argued that the squatters should be legalized and given title deeds, the Turkish technocrats fiercely argued against this idea, indicating the emergence of squatter landlords owning entire squatter neighborhoods. Hart found the resistance of the technocrats "surprising", since he observed that "owning a home seems to be a strong desire among the squatters, if not Turkish people in general" (Hart 1964). ${ }^{5}$ Despite the technocrats' objections, the legalization of gecekondu via title deeds would become the common policy in the following years. Shaping Turkish urbanization drastically from the 1960s onwards, the gecekondu would become a favorite subject in various domains of cultural production and also be the major theme for politics and social sciences (see Sewell 1964; Hart 1969; Kiray 1970).

The desire to have a home did not necessarily mean to own property for the squatters in the 1960s. It was rather a quest for security in the city since they were under constant threat of evacuation. And this longing had been there since the earliest of gecekondu appeared in the big cities. The well-known poet Orhan Veli's verses from 1947 provide a fine representation of the desire for a home for the part of the squatters:

they move in to a cozy apartment.

neither cleaning nor doing laundry [for others] any more;

the dishes she washes are theirs only.

they have a charming baby;

and buy a second hand car.

\footnotetext{
4 In fact, the debates on extravagance was a result of the clash between on the one hand the rise of a new bourgeoisie (and its visibility in popular media) and the demonization of consumerism within the ideological climate of statist developmentalism, rather than the quantitative dominance of "luxury" housing.

5 Hart's study, conducted in 1962 and 1963, had a considerable influence on later studies, as well as government policies; his basic proposals were followed by the authorities.
} 
they go to Kizllay Park in the mornings;

for little Yllmaz to play in the sand,

like the children of the wealthy

(Veli 1947)

The longing for a cozy apartment became a theme in Turkish cinema as well. ${ }^{6}$ In the opening scene of Acl Hayat [Bitter Life] (1962), director Metin Erksan plays into the homonymy of "evlenmek" in Turkish, which means "getting married" and "obtaining a home" at the same time. The female protagonist declares her love to her lover and affirms his request to get married: "let's get married; let's have a home". The lovers search for a home but those they like are too expensive and the ones they can afford are in terrible conditions. The couple cannot help but drop into the newly built apartment blocks, where each room is "as big as the houses they currently live in," although they know that they are beyond their reach. Later on, the seduction of the female protagonist by a rich man leads to their break up and when the male protagonist gets rich, he builds himself a new villa, which can be interpreted again in relation to the homonymy of "evlenmek". He substitutes love/ marriage with home ownership. Moreover, he does not want a home which belonged to someone else, but a virgin one. Here, home assumes gender identity. It is also significant that the villa is located in Kilyos, where there are summer houses of the rich, one of which was the place where the female protagonist was seduced. $^{7}$

The association of marriage and home is also found in Halit Refiğ's Krnk Hayatlar [Broken Lives] (1965). The film opens with the entrance of the female protagonist into the new home she and her family are moving into. The husband is a young doctor who had no inheritance but earned his social status by working hard. Interestingly, although Refiğ was loyal to the original story which was a novel by Halid Ziya Uşaklıgil, one of the few changes he made was the separation of the doctor's office from the house. The modern separation of home and workplace leads to the emergence of the former as a space of boredom and alienation for the middle class. The young doctor grows distant from his wife and neglects his family; this results in the eventual death of his daughter. In the end, the vacant

6 For a similar discussion focusing on the revival of the films of this period in contemporary Turkey and their role in the urban imaginary, see Ipek Türeli, Istanbul Open City: Exhibiting Anxieties of Urban Modernity (London and New York: Routledge, 2018), 50-78. The films discussed here can be presently seen on YouTube.

7 Atakav discusses the representation of women in Turkish cinema, especially in the 1980s, in relation to the rise of feminism. One section of the study (pp. 38-49) is allocated to the discussion of the melodramas in the 1950s and the 1960s. Eylem Atakav, Women and Turkish Cinema: Gender Politics, Cultural Identity and Representation (London and New York: Routledge, 2013). 
home becomes a sign of the broken family and a stage for the final act of suicide, which is prevented by the arrival of the wife and the reconciliation of the couple.

The desire to have a house of one's own provides the main theme in Ertem Göreç's Otobüs Yolculan [Bus Passengers] (1961), a film considered as an example of the short-lived social realist genre in Turkish cinema. ${ }^{8}$ The film depicts the manipulation of the desire of the poor to obtain a home by the greedy owner of a construction company. With its particular concern for social critique, this film presents one of the earliest depictions of gecekondu areas as the positive antithesis of opulent bourgeois homes, which would find its way even into the melodramas in the following decade. Nonetheless, Göreç views gecekondu as a temporary phenomenon and affirms the squatters' wish to move in to modern apartments. This view is in tune with the ideological climate of the early 1960s and the technocrats' approach to the housing question as illustrated in the beginning of the chapter.

Within the context of rapid urbanization in the wake of the Second World War, it was not only the squatters who were under the threat of homelessness. The political economy of real estate expanded the social base of the housing question. The shortage of housing raised the rents, which turned housing into an issue for the lower middle classes - especially petty bourgeois professionals and low rank state officials - as well. By the early 1950s, land prices in the major cities reached high levels which made home ownership in the city center an unattainable luxury. Since the legal framework did not allow for flat ownership, the only way to own a house was to acquire a lot individually, and the increasing land prices in the cities made this impossible. In the absence of flat ownership, city centers of major cities were full of run-down (or torn-down) buildings failed to be replaced with new ones despite the municipalities' encouragement via increased building heights in the 1950s (Batuman 2017, 26-32).

In the context of the growing heterogeneity of the urban environment, insufficiency of infrastructure and services, and the rising cost of living, home ownership was seen as a means of social security in the ever-increasing chaos

8 Social realism in Turkish cinema is generally considered to last between 1960 and 1965 and is associated with a small number of directors including Metin Erksan, Halit Refiğ, Ertem Göreç, and Duygu Sağıroğlu. See Aslı Daldal, 1960 Darbesi ve Türk Sinemasinda Toplumsal Gerçekçilik (Istanbul: Homer, 2005); Agah Özgüç, Türlerle Türk Sineması: Dönemler, Modalar, Tiplemeler (Istanbul: Dünya, 2005). While the earlier works depicted social conflicts in village life, the city rapidly came to the foreground with its social and physical dimensions in the 1960s. In the second half of the decade, some of these filmmakers turned to what they called "national cinema" while a more politically-oriented lineage, represented especially by Yllmaz Güney, also emerged towards the end of the decade. 
of the metropolis. ${ }^{9}$ An interesting phenomenon which made home ownership attainable - at least for the lucky few - was the lottery houses. The banks had been building and distributing houses to their clients as early as the 1930s (Şumnu 2014, 51-73). Begun as an attempt to encourage upper classes to use savings accounts, the lottery houses proved to be an effective means to attract clients. While the earliest ones were single-family villas, they gradually increased in number and turned into small multi-unit blocks (Bozdoğan and Akcan 2012, 150; Şumnu 2014, 51-73). The transformation of the lottery houses from large villas into smaller flats both increased the chance to win a house and contributed to the cultural influence of the apartment block. Hence, in the 1950s and the 1960s, attaining a home beyond the reach of one's economic limits was a probability sustaining the desire for home ownership.

\section{The Apartment Block}

With the increasing number (and visibility) of gecekondus, the apartment gradually began to signify the contemporary form of dwelling. Not only the run-down quarters that required renewal but even modern villas and cooperative houses from the 1930s were replaced with apartment buildings. In this regard, the apartment building, in addition to being the material form embodying modernity, was also a "mechanism of modernization" providing the possibility for the middleclasses to achieve residences with modern amenities (Gürel 2015, 39-40). ${ }^{10}$

The most important dynamics of the rise of the apartment block was the change in the Land Registration Act in 1954, which allowed for the de facto implementation of flat ownership. Interestingly, until the definitive institutionalization of flat ownership in 1965, architects often treated the apartment block as an architectural whole rather than an ensemble of identical units. Hence, the period between the mid-1950s and mid-1960s witnessed the finest architectural

9 This urban condition would assume political forms in the second half of the decade with growing workers' movements, students' occupations, and peasant protests. The political tension in the cities would further escalate with the radicalization of the squatters. See Erman (this volume).

10 Although I do not discuss it here, it is crucial to consider the gendered character of the apartment as modern home equipped with technological appliances. For the gender politics of domestic architecture see Beatriz Colomina, ed., Sexuality and Space (Princeton: Princeton Architectural Press, 1991); Diana Agrest, Patricia Conway, and Leslie K. Weisman, eds., The Sex of Architecture (New York: Harry N. Abrams, 1996); Jane Rendell, Barbara Penner, and Iain Borden, eds., Gender Space Architecture: An Interdisciplinary Introduction (London: Routledge, 2000). 
examples of apartment blocks. ${ }^{11}$ The shared volumes in these buildings were treated carefully as social spaces. Nevertheless, the revision of the Land Registration Act triggered the rapid construction of apartment blocks with the hands of small contractors. While the real estate market was boosted, the new regulation also allowed for the reconstruction of the city centers and the renewal of urban fabric in the form of identical apartment blocks throughout the Turkish cities. Even larger housing projects were built in the form of tall multi-family blocks rather than the garden city principles (with low-rise buildings and large open spaces) that guided the earlier housing schemes (Bozdoğan and Akcan 2012, 150-152).

Aside from being a symbol of modernity, the apartment building was also economically advantageous, and it was supported by the technocrats of the State Planning Organization (DPT) and the Ministry of Reconstruction and Resettlement seeking optimization in housing production. A major instrument believed to efficiently control the "waste" of resources for luxurious housing was "people's housing standards," which were implemented in 1964. Accordingly, the maximum floor area of a housing unit eligible for public loans was determined as $63 \mathrm{~m}^{2} .^{12}$

The gradual expansion of the apartment block across social strata requires a discussion of its architectural culture. The earlier examples (between mid-1950s and mid-1960s) were often built as family apartments and the common spaces of the buildings were treated accordingly. With the emergence of small contractors and the construction of apartments for the market rather than the landowners, these communal spaces began to deteriorate as symptoms of the retreat of modern families into their secluded cells. Orhan Pamuk's depiction of the transformation of the light well of an apartment block into a dark pit with the construction of another building in the adjacent lot illustrates this metamorphosis:

How to describe this dread funnel bringing mystery and death to our windows? Some called it the gap. Others called it the dark air shaft... Of course there were those who insisted these new spaces let in light, not darkness, though most of us hated them... a dark, dead space hemmed in by dirty, discolored, concrete walls, between windows reflecting other windows into infinity...

(Pamuk 2006a (Black Book), 206-207)

11 For a study on the history of apartment blocks in the case of Ankara, see Nuray Bayraktar et. al., “Ankara'da 1930-1980 Yılları Arası Sivil Mimari Kültür Mirası: Araştırma, Belgeleme ve Koruma Ölçütleri Geliştirme Projesi,” TUBITAK 110K600 (unpublished report, 2014).

12 The limit value for the floor area was intensely debated. It would first be increased by $10 \%$ $\left(69.3 \mathrm{~m}^{2}\right)$, and finally raised to $100 \mathrm{~m} 2$ in 1966 under the pressure from the unions. The failure to implement an efficient level for the social housing standards, needless to say, resulted in the limited attempts to support mass housing to gain a middle-class character. See TEKSIF, Konut Semineri: Tebliğler ve Görüşler (Ankara: TEKSİF, 1964). 
The increasing dominance of small contractors in the construction sector resulted in the rapid decline of architectural quality and the characterization of apartments with anonymity and banality. Yet, this does not mean that this residential type lacks architectural meaning. On the contrary, the anonymous apartment represents the anonymization of the client for the part of the architect. This would become the major argument of a radical generation of socialist architects who sought to develop a social critique of architecture. ${ }^{13}$ For instance, in the Architecture Seminar organized by the Chamber of Architects in 1969, several participants argued that the clients of architecture were no longer a dominant minority but rather the society as a whole. The architect was faced by a new historical condition marked by urbanization; the collectivized demand for architecture (especially housing) had turned the architect into a technician serving society rather than the autonomous, talented professional of the previous age serving the rich (Kuban 1969). ${ }^{14}$ This redefinition of the architectural profession was an attempt to locate the professionals within the process of selfhelp gecekondu housing which was taking place outside the legal building procedures - that is, without the involvement of architects.

If we turn to the architectural space of the apartment, it also represented an obscure urban space; it did not reveal what happed inside. Contrary to detached house clearly displaying the social status of its owner as well as the functional distribution of spaces in it, the apartment was a black box concealing its interior. It could be an attainable home for the lower classes, a modern residence for a wealthy family, and even used for other purposes. In Halit Refiğ's Gurbet Kuşlan [Birds of Exile] (1964) the migrant family arriving in Istanbul settles in a worn out house as tenants, while the enlightened bourgeois family lives in a spacious apartment. But more interestingly, as the immigrant family gradually sinks down to its doom, the daughter runs away and becomes a prostitute. When the brothers trace her to an apartment block, they have to check the flats one by one until they find her in an apartment used as a brothel. The scene continues with a chase to the rooftop where the girl is cornered. Here the cityscape is masterfully used in the background to simultaneously provide a view of Istanbul and the entrapment of the unfortunate girl within the evils of the urban. The apartment serves as a

13 The gradual radicalization of the younger generations of architects in the 1960s was related to the political climate as well as the worsening economic conditions of the profession. For a detailed discussion, see Bülent Batuman, "Organic Intellectuals of Urban Politics? Turkish Urban Professionals as Political Agents in 1960-1980,” Urban Studies 45/9 (2008): 1925-1946.

14 This was a major theme of fierce discussions in the historic "Architecture Seminar" organized by the Chamber of Architects in 1969. See Chamber of Architects, Mimarlk Semineri (Ankara: Chamber of Architects, 1969). 
vertical model for the illegibility and the dangers of the metropolis. In the end, the girl jumps to her death from the rooftop with nowhere to turn to.

\section{The Bourgeois Home}

The architectural profession enjoyed a period of success in terms of residential architecture beginning with the 1950s in Turkey. The decade witnessed the rise of a new generation of Turkish architects who came to prominence through architectural competitions and especially the single-family houses they designed. These modern homes were waterfront houses or large villas overlooking the Bosphorus, and they were designed for the new bourgeoisie comprising industrialists, businessmen, and professionals in Istanbul (Bozdoğan and Akcan 2012, 141).

Home decoration was also an important component of these residences. In Turkey, up until mid-1950s, neoclassical European style furniture was preferred by the affluent families. The reason for this was the owners' desire to connect themselves with the late Ottoman aristocratic taste (Gürel 2009, 51). This kind of furniture was especially used in the living rooms, the public face of the houses where the guests were accepted. The furniture in the bourgeois living room was supplemented with luxurious goods as well: chandeliers, vases, chinaware, etc. were always displayed, frequently in special glass cabinets. Exhibition was always more important than comfort. As Pamuk depicts in his memoirs, "Sitting rooms were meant not to be places where you could lounge comfortably; they were little museums designed to demonstrate to a hypothetical visitor that the households were westernized ... To my childish mind, these rooms were furnished not for the living but for the dead." (Pamuk 2006b (Istanbul), 10)

The living room then was a showcase for the gaze of the visitor rather than a space for the household. This aspect of the bourgeois home, that it is organized around a central space of display which is least connected to the domestic life in the house, has been the basic image used in Turkish cinema to represent the bourgeois lifestyle. In the films, the rich live in either big mansions or modern villas, which are located in large gardens or on the waterfront alongside the Bosphorus. As the dramatic structure is always constructed through a love affair between the rich girl and the poor boy (or vice versa), the contrast between the homes of the poor and the rich becomes important. The bourgeois home represents a western lifestyle, which is equated with decadence, immorality, hedonism, and selfishness. The equation of the lower class with the local culture of the East and the upper class with the foreign culture of the West was a common trait in the melodramas. The upper class was the object of desire but also the 
source of moral corruption (Dönmez-Colin 2008, 31). In the films, the living rooms of the upper-class residences are filled with luxurious objects and furniture signifying wealth. The living rooms frequently become a stage for parties, which operate as the demonstration of decadent bourgeois life in the eyes of the protagonist representing lower classes (Arslan 1997).

It is crucial to note that the dominant taste among the new bourgeoisie began to change parallel to the redefinition of Western modernity with reference to the US instead of Europe (which itself was going under American influence due to the Cold War geopolitics), in the second half of the 1950s. As witnessed by the changing images in architectural magazines, modern designs characterized by unadorned furniture made of new materials came to the foreground. A major source for inspiration was the construction of the Istanbul Hilton Hotel in 1952-55 (Gürel 2009, 55-59; Bozdoğan and Akcan 2012, 116-121). The Hilton Hotel redefined modern architecture in Turkey with its interior decoration as well as its iconic building form, which also found its way into the popular imaginary through Yeşilçam films. Nevertheless, in the films of the 60s, there is no clear cut demarcation between neoclassical and modern furniture. Often mansions with flamboyant furniture were associated with the older generation and the patriarchal structure of wealth, and the villa with modern furniture was the setting for the "immoral acts" of a spoiled son.

In terms of architecture, the interiors had specific features that were associated with bourgeois lifestyle. The fireplace, for instance, was a common element and especially a detached one signified modern decoration. In the films, we often see a piano located in the living room. Finally, the most crucial element was the staircase, which suggested the size of the house and also hinted at the private spaces upstairs. The spectator is constructed as the visitor in the living room and the frames displaying bourgeois homes in the films are strikingly similar to the architectural photographs in popular and professional magazines. The interior of the bourgeois home, then, is visually coded through what it displays and hides. Here, display demonstrates power and insinuation triggers fantasy. In this way, the bourgeois home is constructed through a love-hate relationship (simultaneously an object of desire and disgust) especially in the melodramas.

The melodrama is marked by the audience's desire for, and wish to be desired by, the bourgeoisie, which reflects the wish of the squatters to be a legitimate part of the urban order (Erdoğan 1998, 265). Throughout the 1960s, becoming a part of the urban system, for the squatters, meant to transform into the acceptable form of urban dwellers. The transformation required for recognition meant changing identities and shifting social positions. Therefore, we often see the protagonists suddenly getting rich or becoming famous in the films. They even change identities to surprise their lovers or to get revenge. While these movements across the 
class-bound social topography represent a desire for upward mobility, what is crucial is that the social order remains intact. Even if the heroes climb the social ladder and the villains lose their power, the social hierarchy has to be maintained. Significantly, it is the bourgeois home that functions as an anchor to fix meanings and identities within the social network and preserve harmony. Destruction of architecture as a signifier of social order is not something that we see in the films in the 1960s.

A striking treatment of the bourgeois home can be found in Metin Erksan's Sevmek Zamanı [Time to Love] (1965). The film, which received critical acclaim, is hard to categorize since it is neither a typical melodrama nor raises social issues (Y1ldirım 2014, 352-371). The story focuses on the idea to fall in love with an image. A house painter falls in love with the photograph of a girl he sees in a villa he is painting and he begins to spend time in this house watching the photograph even after his work is finished. Here the bourgeois home is visualized as vacant; it is either emptied and left to the workers, or abandoned for the winter. In the film, the summer resort of Istanbul's upper classes in Büyükada (Prinkipo of the Princes' Islands) appears deserted in winter. Curiously, the opening sequence shows the protagonist walking in the rain, arriving in a house and entering comfortably. Although he jumps over the garden fences, he has a key to the house and his movements inside are so comfortable that the spectator does not suspect that he is an intruder. The emptiness of the bourgeois home and its occupation by others do not refer to political conflicts in the film. Yet, the story is set in a bourgeois environment, and in the end, the disastrous end comes with the hands of an egotistical bourgeois villain.

\section{The Circulation of the Image of Bourgeois Home}

It is necessary to point out that the visual construction of the bourgeois home in the eyes of the spectators was by no means a one-sided process. The audiences were not passive recipients of the films. Although Turkish cinema flourished through private enterprises after the 1950s, the level of capital accumulation in the sector was so low that the filmmakers depended on the prepayments they received from the local distributors. As a result, they had to take into consideration the expectations of the audience as communicated by the distributors. The spectators also expressed their views on the films through letters they sent to popular magazines (Mutlu 2010, 417-431). Most of these letters either directly addressed or indirectly discussed the movie stars. The actors' appearance in similar roles in high numbers of films produced every year led to their recognition as themselves in the 
films rather than the characters they impersonated. Additionally, the technical pressures to speed up production also reduced the use of cinematic instruments empowering the identification mechanisms such as shot/ reverse-shots and other point-of-view shots (Erdoğan 1998, 266; Gürata 1997, 62-63). Failure of identification with the characters allows the audiences to feel themselves in direct contact with the actors. This is visible in the audience letters fantasizing about a better life with the actors as objects of desire within these fantasies. For instance, one fan addressed Fatma Girik (one of the top female stars of the period) in his letter sent to the magazine Sinema: "I should earn 1500 TL instead of 600. We should live in a fabulous apartment. We should own tapes, telephones and gramophones ... I should arrive home at $6 \mathrm{pm}$ with packages filled with bread and meat ... You should prepare my meal and serve my drink ... We should be together forever." (quoted in Mutlu 2002, 205)

Interestingly, the repetitive appearance of actors in similar roles is also true for the use of the houses used as the homes of the rich. The same mansions and villas were used in several films to the extent that they would be identified by the spectators. One example is the Sadıkoğlu House in Ortaköy, which was later demolished for the construction of the Bosphorus Bridge. The interior of this house was used in numerous films (for instance, Kanun Benim [I am the Law] (1966), Ayşecik'le Ömercik (1969)); sometimes it was used together with the outside views of different villas (Kaderimsin [You are my Destiny] (1969). Other often-used mansions were the Nazım Kalkavan House in Beylerbeyi with its iconic towers (Hıçkırk [Sob] (1965)) and the Ziya Kalkavan House in Yeniköy. In addition to these older mansions, there were also frequently used modern villas such as the İkiz Yalı in Kanlıca (Sonbahar Rüzgarlan [Winds of Autumn] (1969)). But the most famous one was the Muammer Karaca villa with its well-known interior murals.

The recognition of the houses operates differently than the suppression of the characters by the real identities of the actors enacting them. The house seen in a film is also a bourgeois home in real life; hence the negative connotations of bourgeois life (i.e. association with moral corruption) represented by the house are transferred to the cultural codes of everyday life. In other words, the bourgeois homes in the melodramas were conceived not as film décor but as actual architecture. In this respect, they amplified the hostility towards luxurious housing as illustrated by the Chamber of Architects declaration quoted in the beginning of this chapter.

Moreover, the actors themselves, whose lives as stars attracted attention, also reproduced the conventions constructed in the films. A significant example illustrating this issue is a serial entitled “Actors and their Homes" published in the popular magazine Ses during 1966. Successive issues of the magazine published photographs of the actual homes of famous movie stars such as Filiz Akın, 
Sadri Alışık-Çolpan İlhan, Zeki Müren, Ediz Hun, Neriman Köksal, and Ayhan Işı. The homes of these famous figures generally were lavishly decorated apartments, and the articles often contained information regarding the prices of the houses or the furniture. The decorations displayed a hybrid taste with distinct styles existing side by side within the same house. For instance, Sadri AlışıÇolpan İlhan House had a "Renaissance style hallstand", a "Louis XIV style living room" and "Louis Philippe style armchairs" together with Picasso reproductions on the walls (Artistler ve Evleri 3, Sadri Alışık/ Çolpan Ilhan, Ses 13, March 26, 1966). Similarly, Tamer Yiğit's home had "an Italian dining room," "American style couches" in the living room, "a traditional Anatolian saddlebag" hung by the couches, an "expensive antique vase" on a modern table and a cabinet exhibiting "chinaware from Germany and Czechoslovakia.” (Artistler ve Evleri 10, Tamer Yiğit, Ses 20, May 14, 1966). Ayhan Işık's house, on the other hand, had "English style armchairs", a "French style coffee table" and a "Chinese tea set on a cabinet.” (Artistler ve Evleri 12, Ayhan Işık, Ses 22, May 28, 1966)

The most highlighted pieces of furniture in these living rooms were the music cabinets (TV sets did not exist yet) and American bars displaying alcoholic beverages. The actors themselves posed in each room, imitating their domestic practices. In the bedrooms they posed in their pajamas, morning gowns or bathrobes. The representations of the actors' homes were as constructed as the bourgeois homes they resided in the films. Here, they were enacting themselves, or rather the public images they wanted to create, which in turn were very much connected to the characters they portrayed on screen. Hence, to maintain the audiences' fantasy, they presented themselves as proper bourgeois using expensive furniture. That is, the "real life" images the actors constructed for themselves were part of a larger economy of desire and representation. This endeavor also affected the representation of the bourgeois home. As the real life images of the actors moved closer to the parts they played, the representation of bourgeois home was circulated outside the films.

\section{Conclusion}

In the 1960s, cinema was very effective in constructing the visual representation of the bourgeois home, which was presented as an object of desire and hate at the same time. It was both the symbolic object of desire representing upward social mobility and the signifier of social inequality. While the political climate radicalized with the rising popular movements in the second half of the decade, Turkish cinema moved further away from politics. This was due on the one hand 
to the presence of censor, and on the other the audience's disinterest in political cinema. In fact, the mid-1960s witnessed the decline of social realism and the solidified dominance of melodramas. Within this context, social meanings of residential architecture produced through various media became components of the architectural culture of the period. Privately owned houses were experienced as urban artifacts by the rich and the poor alike. This let the politics of housing gain a cultural dimension as well and turned the bourgeois home into a component of the politics of housing.

By the second half of the 1960s politics was gradually assuming urban forms and the representation of bourgeois home already had subtle yet powerful political connotations. In the following decade, it would be represented as a component of the housing question experienced by the squatters in the form of open political clash. The representation of social injustice through the oppression faced by the squatters meant the depiction of the city as a political sphere. Even the melodramatic conflicts would be situated within this political context in the 1970s. Housing would frequently be presented as a specific domain of exploitation and the bourgeois home would grow to be an overt manifestation of political hatred. Interestingly, this shift occurred through the emergence of arabesk in the Turkish melodramas (Özbek 1997, 211-232; Arslan 2005, 79-81). Beginning as early as 1971, arabesk films with musicians turned actors represented the gecekondu as a signifier of the oppressed squatters and an antithesis to the bourgeois home. The gecekondu neighborhood would represent unity and solidarity among the squatters, who stood together (generally at the end of the film) against the rich villains.

\section{Bibliography}

“Artistler ve Evleri (3) Sadri Alışık - Çolpan İlhan.” Ses 13, March 26, 1966.

"Artistler ve Evleri (10) Tamer Yiğit." Ses 20, May 14, 1966.

“Artistler ve Evleri (12) Ayhan Işı.”. Ses 22, May 28, 1966.

“Küçükyalı’da İki Villa.” Arkitekt 325 (1967): 8-11.

Agrest, Diana, Patricia Conway, and Leslie K. Weisman, eds. The Sex of Architecture. New York: Harry N. Abrams, 1996.

Altun, Didem A., and İnci Uzun. “Yeşilçam Sineması'nda Mekân Kullanımı.” Mimarlık 366 (2012): 50-55.

Arslan, Savaş. "Center vs. Periphery: Visual Representation of the Party Scenes in Yeşilçam Melodramas.” Master's thesis, Bilkent University, 1997.

Arslan, Savaş. "Hollywood Alla Turca: A History of Popular Cinema in Turkey." Ph. D. dissertation, Ohio State University, 2005.

Atakav, Eylem. Women and Turkish Cinema: Gender Politics, Cultural Identity and Representation. London and New York: Routledge, 2013. 
Batuman, Bülent. "Turkish Urban Professionals and the Politics of Housing, 1960-1980." METU Journal of the Faculty of Architecture 23/1 (2006): 59-81.

Batuman, Bülent. "Organic Intellectuals of Urban Politics? Turkish Urban Professionals as Political Agents in 1960-1980.” Urban Studies 45/9 (2008): 1925-1946.

Batuman, Bülent. “Ankara'da Cumhuriyet Dönemi Konut Mimarlı̆ı̆ın Gelişimi Üzerine Bir Dönemleme Denemesi." In Sivil Mimari Bellek Ankara 1930-1980, edited by Nuray Bayraktar, 11-51. Ankara: VEKAM, 2017.

Bayraktar, Nuray, et. al. “Ankara'da 1930-1980 Yılları Arası Sivil Mimari Kültür Mirası: Araştırma, Belgeleme ve Koruma Ölçütleri Geliştirme Projesi.” TUBITAK 110K600, unpublished report, 2014.

Bozdoğan, Sibel, and Esra Akcan. Turkey: Modern Architectures in History. London: Reaktion Books, 2012.

Can, Tulgar. "Kalkınma Planı Açısından Konut Davamız.” In Konut Semineri. Ankara: TEKSIF, 1964.

Chamber of Architects. Bildiri 1960: Yurdumuzda Imar Çabaları. Ankara: Chamber of Architects, 1960.

Chamber of Architects. Mimarlık Semineri. Ankara: Chamber of Architects, 1969.

Colomina, Beatriz, eds. Sexuality and Space. Princeton: Princeton Architectural Press, 1991.

Daldal, Aslı. 1960 Darbesi ve Türk Sinemasında Toplumsal Gerçekçilik. Istanbul: Homer, 2005. Dönmez-Colin, Gönül. Turkish Cinema: Identity, Distance and Belonging. London: Reaktion Books, 2008.

Erdoğan, Necmi. "Narratives of Resistance: National Identity and Ambivalence in the Turkish Melodrama between 1965 and 1975." Screen 39/3 (1998): 259-271.

Gürata, Ahmet. “Filmic Space in Turkish Melodrama.” Master’s thesis, Bilkent University, 1997.

Gürel, Meltem 0. "Consumption of Modern Furniture as a Strategy of Distinction in Turkey." Journal of Design History 22/1 (2009): 47-67.

Gürel, Meltem 0. "Seashore Readings: The Road from Sea baths to Summerhouses in midtwentieth century İzmir." In Mid-century Modernism in Turkey: Architecture Across Cultures in the 1950 and 1960s, edited by Meltem Ö. Gürel, 27-54. London and New York: Routledge, 2015.

Hart, Charles. "Istanbul Gecekondularında Yapılan Araştırmaların Ilk Sonuçları.” In Konut Semineri. Ankara: TEKSIF, 1964.

Hart, Charles. Zeytinburnu Gecekondu Bölgesi. Istanbul: Chamber of Commerce, 1969.

Karpat, Kemal. The Gecekondu: Rural Migration and Urbanization. Cambridge, London, New York, Melbourne: Cambridge University Press, 1976.

Kaya Mutlu, Dilek. "Yeşilçam in Letters: A "Cinema Event" in 1960s Turkey from the Perspective of an Audience Discourse.” Ph.D. dissertation, Bilkent University, 2002.

Kaya Mutlu, Dilek. "Between Tradition and Modernity: Yeşilçam Melodrama, its Stars, and their Audiences." Middle Eastern Studies 46: 3 (2010): 417-431.

Keleş, Ruşen, and Danielson, Michael N. The Politics of Rapid Urbanization. New York and London: Holmes \& Meier, 1985.

Kıray, Mübeccel. "Squatter Housing: Fast De-Peasantization and Slow Workerization in Underdeveloped Countries." Paper presented to the 7th World Congress of Sociology, Varna, 1970. 
Kuban, Doğan. "Toplum açısından mimarlığın tarihsel gelişimi ve toplumsal yapı değişikliklerinin mimarlığın evrimine etkileri.” In Mimarlık Semineri, n.p. Ankara: Chamber of Architects, 1969.

Özbek, Meral. “Arabesk Culture: A Case of Modernization and Popular Identity”. In Rethinking Modernity and National Identity in Turkey, edited by Sibel Bozdoğan and Reşat Kasaba, 211-232. Seattle: University of Washington Press, 1997.

Özgüç, Agah. Türlerle Türk Sineması: Dönemler, Modalar, Tiplemeler. Istanbul: Dünya, 2005. Pamuk, Orhan. The Black Book. New York: Vintage Books, $2006 \mathrm{a}$.

Pamuk, Orhan. Istanbul: Memories and the City. New York: Vintage Books, 2006b.

Rendell, Jane, Barbara Penner, and lain Borden, eds. Gender Space Architecture: An Interdisciplinary Introduction. London: Routledge, 2000.

Sewell, Granville H. "Squatter Settlements in Turkey: Analysis of a Social, Political and Economic Problem.” Ph.D. dissertation, M.I.T, 1964.

Şumnu, Umut. “Ankara'daki (İ̧̧ Bankası) İkramiye Evleri.” Ankara Araştırmaları Dergisi 2/1 (2014): 51-73.

TEKSiF. Konut Semineri: Tebliğler ve Görüşler. Ankara: TEKSIF, 1964.

Türeli, İpek. Istanbul Open City: Exhibiting Anxieties of Urban Modernity. London and New York: Routledge, 2018.

Veli, Orhan. “Altındağ.” In Yenisi. Istanbul: İnkılap, 1947.

Yıldırım, Tunç. “Metin Erksan'ın Sevmek Zamanı Filminin Eleştirel Alımlanması.” Global Media Journal: TR Edition 5/9 (2014): 352-371. 